\title{
Impact of Covid -19 on Education: Rise of e-
}

\section{learning}

\author{
Mrs. Eesha Sharma \\ Librarian, P.G. Department \\ MIER College of Education (Autonomous), Jammu-180001 \\ eesha.sharma@miercollege.in
}

\begin{abstract}
The impact of pandemic COVID-19 is observed in every nook and corner of the world, in each and every sector right from the health, business, economy, information technology and education etc. The education sector of the whole world is disrupted .The pandemic enforced the world wide lock down. The Covid-19 has brought the whole world into its knees and jolted the global economy. It has adversely affected the education sector resulting into closure of more than $90 \%$ of schools, colleges and universities. More than 1.2 billion students were out of the classroom. As a result, education has changed radically, with the distinctive rise of e-learning which was widely accepted, whereby teaching is undertaken remotely and on digital platforms. The purpose of this paper is to draw the attention of all educators to provide the education in an effective manner. The paper also highlights the digital initiatives of government to cope up with the pandemic. The paper suggests that e-learning has been shown to increase retention of information in less time.
\end{abstract}

Keywords: Covid-19, Education, e-learning, Government of India

\section{INTRODUCTION}

The pandemic Covid-19 has spread all over the world and jolted the global economy. It has significantly disrupted the education sector. On February 11, 2020, the world Health Organisation (WHO) officially announced the name of the virus as COVID-19.'CO' stands for corona, 'VI' for virus, and 'D' for disease. . Formerly, this disease was referred to as '2019 novel coronavirus' or '2019-nCoV'.It was first reported in Wuhan, Hubei Province, China in December 2019. On March 11, 2020, the WHO declared Covid-19, a global pandemic due to the speed and scale of the transmission of the disease. The first case of Covid-19 infection in India was reported in Kerala, state on January 27, 2020 and the affected had a travel history from Wuhan, China as she had returned to Kerala from Wuhan on January 23, 2020 owing to Covid -19 outbreak situations there. On March 24, 2020, the Government of India under Prime Minister $\mathrm{Mr}$. Narendra Modi ordered a nationwide lock down for 21 days, limiting movement of the entire 1.3 billion population of India as a preventive measure against the Covid-19 pandemic in India. WHO suggested maintaining social distancing as the first preventive measure. So every country started the act of lock down to separate the infected people. According to the UNESCO report, it had affected more than $90 \%$ of total world's student population during mid April 2020 
Volume 9 Issue 2 February 2021

which is now reduced to nearly $67 \%$ during June 2020 . Breakout of Covid-19 has impacted more than 120 crores of students and youths across the planet. [1] Covid-19 outbreak has created educational disruptions. The pandemic has changed the life styles of the entire world drastically with billions of people being forced to say at home to remain safe and to learn and to work from home. [2]

The Covid-19 pandemic forced schools to shut abruptly. It disrupted the entire education sector. More than 1.2 billion children were out of the classroom. It has enforced the world wide lock down and the whole world is at halt. [3] Future of the students is at stake but educational institutions have accepted this challenge and provide seamless support and guidance to their students in this pandemic. Indian Education System got the opportunity to transform the traditional classroom teaching to virtual teaching and this is the distinctive rise of e-learning. Initially the educators and students were confused as what to do and how to cope up in this pandemic because many institutions were compelled to cancel their classes, / entrance examinations and internships etc. But it is the right time to switch classroom teaching - learning to elearning. e-learning has given them hope to carry all their educational activities in an effective manner. Educators assign work to students via internet, delivered lectures through video-conferencing by using different Apps such as Zoom, WebEx, Google Meet, and Google Classroom etc. Even students use different social media like You tube Live, Facebook Live, Telegram, Whats app to cope up with the pandemic and to adopt new teaching - learning technologies [1] and [4]

\section{CONCEPT OF E-LEARNING}

e-learning has become a significant component in all schools, colleges, Universities throughout the world due to the pandemic. It provides an effective teaching method and brings out the best from students. [5] e- learning is basically electronic learning i.e. the learning through electronic technologies and digital resources. It is provided through electronic devices like laptops, computers, tablets or even cellular phones which are connected to the internet. It is very impactful and convenient as one can learn it from anywhere and at any time. The other names of e-learning are: online learning, online education and mobile learning etc. [6]

\section{DIGITAL INITIATIVES OF MHRD ON EDUCATION DURING COVID-19}

To address the challenge of remote learning MHRD has undertaken several initiatives in online teachinglearning for students, scholars, teachers and lifelong learners by providing different platforms, e-portals and educational channels through Direct to Home TV, Radios for students to continue learning, to enhance, to strengthen and to broaden their horizons for knowledge. A comprehensive initiative called PM eVIDYA was announced on May17, 2020 which aims to unify all efforts related to digital/online/on-air education to enable equitable multi-mode access to education. It is envisaged that it will benefit nearly 25 crore school going children across the country. [7] The digital initiatives of MHRD for secondary and higher education during COVID-19 are as under:

\subsection{Secondary Education}

3.1.1 DIKSHA (Digital infrastructure for Knowledge Sharing)

DIKSHA is the national platform for school education available for all states and the central government for classes 1 to 12.It can be accessed by teachers and learners across the country.It currently supports 18 languages and the various curricula of CBSE, NCERT and SCERTs across India. It can be accessed both online and offline. The platform is being leveraged and developed for school education, foundational learning programs and to support inclusive learning for 
Volume 9 Issue 2 February 2021

underserved and specially-abled communities of learners and teachers. In the context of COVID-19 related disruption of schooling, DIKSHA makes it possible for all states/UT's to enable learning/ education at home through innovative state programs; hence leapfrogging the use of technology for the benefit of teachers and learners across India. The contents can also be viewed through QR codes on textbooks. The app can be downloaded from IOS and Google Play Store. DIKSHA is the 'one nation; one digital platform' for school education in India. [8]

\subsubsection{Radio broadcasting}

It is being used for children in remote areas where online facility is not available (especially for classes 1 to 5). The broadcasts focus on activity-based-learning. 289 Community Radio Stations have also been used to broadcast content for NIOS for classes 9 to 12 .

\subsubsection{ShikshaVani}

A Podcast called ShikshaVani of the Central Board for Secondary Education (CBSE) is being effectively used by learners of classes 9 to12. Shiksha Vani contains over 430 pieces of audio content for all subjects of classes 1 to 12 .

\subsubsection{DTH for Specially-abled}

One DTH channel is being operated specifically for hearing impaired students in sign language. For visually and hearing impaired students, study material has been developed in Digitally Accessible Information System (DAISY) and in sign language; both are available on NIOS website/ YouTube.

\subsection{5 e-Pathshala}

It is a portal developed by NCERT and CIET for classes 1 to 12 in multiple languages including Hindi, English, Sanskrit and Urdu.The textbooks can be accessed by using e-Pathshala web portal and mobile app (Android, iOS, Windows), by students, teachers, teacher educators. It has digital books, video, audio and flip books for classes 1 to 12 .

\subsubsection{National Repository of Open Educational} Resources (NROER)

NROERis an open storehouse of e-content for students, teachers, and teacher educators in multiple languages including e-books, modules and videos including a host of STEM - based games. Content is mapped to the curriculum for classes 1-12. It has a total of 19277 files including 700 collections, 5935 documents, 1453 interactives, 2885 audios, 2583 images, 6421 videos and 441 e-books. [8]

\subsection{Higher Education}

\subsubsection{Swayam}

The Study Webs of Active Learning for Young Aspiring Minds' (SWAYAM) is India's own MOOCs platform offering free online courses on almost all the disciplines. It is a programme initiated by Government of India, for both school (classes 9 to 12) and higher education (under graduate, post graduate). All the courses are interactive, prepared by more than 1000 reputed teachers in the country and are available free of cost. [7]

\subsubsection{Swayam Prabha}

Swayam Prabha is an initiative to provide 32 high quality educational channels through DTH (Direct to Home) across the length and breadth of the country on $24 \mathrm{X} 7$ basis. These channels are available for viewing all across the country using DD Free Dish Set Top Box and Antenna.It covers both school education (classes 9 to 12) and higher education (undergraduate,postgraduate, engineering, out of school children, vocational courses and teacher training ) in arts, science, commerce, performing arts, social sciences and humanities, engineering, 
Volume 9 Issue 2 February 2021

technology, law, medicine, agriculture, etc. The contents are prepared by different MHRD agencies like CEC, IGNOU, IITs, NIOS and NCERT.

\subsection{3 e-PG Pathshala}

It is for post graduate students. Students can access this platform for online courses, e-books, study materials and quizzes. The best part of this platform is that students can take tests and retests on their selected subjects and modules for preparation of their examinations.

\subsubsection{National Digital Library}

The National Digital Library of India (NDL) has been developed byIIT Kharagpur to develop the overall framework of a facility that canprovide a single window access to learners for e-contents/resources. It is also available as Mobile App (Android and iOS) and on UMANG Platform. Anybody can register in NDL at no cost. [7]

\subsection{5 e-Yantra}

e-Yantra is a project entrusted to IIT Bombay for enabling effective education across engineering colleges in India on embedded systems and Robotics. The training for teachers and students is imparted through workshops where participants are taught basics of embedded systems and programming. eYantra also helps colleges to set up Robotics labs/ clubs to make it a part of their routine training curriculum. More than 275 colleges across India have benefited with this initiative. All the projects and code are available on the e-Yantra as open source content. [9]

\section{BENEFITS OF E-LEARNING}

4.1 Accessible: It is easy to access as e-learning method requires only a good internet connection and a gadget like mobile, tablet or computer etc.
4.2 Availability: It is available 24X7. Students can learn from anywhere and at any time.

4.3 Convenient: e-learning is very much convenient as students can attend their classes from anywhere. They only have to connect their class via internet.

4.4 Learning Apps: Students can use different learning apps such as BY JU's, edX, Khan Academy, Kahoot, and Udemy etc. These learning apps are very easy to use [6].

4.5 Maintaining Social Distancing: Now a days social distancing is mandatory for everyone to save their lives so e-learning is the best option for all students, teachers, learners and educators etc. [5]

\section{BARRIERS TO E-LEARNING}

5.1 Digital Divide: Weaker sections of the society may not be able to get computers and internet then this digital divide is the biggest barrier towards e-learning.

5.2 Internet Connectivity: For e-learning good internet connectivity is required. Sometimes some students don't have network connection then it becomes difficult for them to access.

\section{CONCLUSION}

The study reveals that Covid-19 pandemic has adverse effects on education. Though it has created many challenges, various opportunities are also evolved. The outbreak of Covid -19 has taught us that change is inevitable. Education and technology has come a long way and there's a long way to go ahead. Covid -19 has worked as a catalyst for the educational institutions to grow and adopt new platforms with technologies. . The digital push of government has given a fillip to higher education. Learning has not only left the domains of the rooms in the nature of e-learning but has also come to door step of the student in the nature of artificial intelligence and artificial reality. e - learning has 
Volume 9 Issue 2 February 2021

transformed itself into a panacea of rote learning. The teaching model is not just limited to teacher and its intellectual capacity but what more the teacher has to offer in the practicality of the lesson. Now a day's econtent and smart classroom has become the lifeline of education. The technological era is also showering new players in the market with education start-ups viz a viz- DIKSHA, SWAYAM etc. e-learning is the need of the hour and it should be used at maximum. Even the students are getting used to e- content as it is benefitting the students immensely, so it should be continued after the pandemic also. COVID - 19 is proved as blessing in disguise as it has created many opportunities to come out of the classroom teaching model to a new digital era.

\section{REFERENCES}

[1] Jena, P.K. (2020). Impact of Pandemic COVID-19 on Education in India. International Journal of Current Research, 12 (07), 1258212586.

[2] Onyema, E. M., et al. (2020). Impact of Coronavirus Pandemic on Education. Journal of Education and Practice , 11 (13), 108-121.

[3] Choudhary, R. (2020, April 16). Covid - 19 Pandemic: Impact and strategies for education sector in India. Economic Times Government. Retrieved January 11, 2021 from https://government.economictimes.indiatimes.com /news/education/covid-19-pandemic-impact-and$\underline{\text { strategies-for-education-sector-in-india/75173099 }}$

[4] Marinoni, G., Land, H., \& Jensen, T. (2020). The Impact of Covid-19 on Higher Education Around the World. France: International Association of Universities.

[5] Radha, R., Mahalakshmi, K. Satishkumar, V., \&Saravanakumar, A.(2020). E-Learning during Lockdown of Covid-19 Pandemic: A Global
Perspective. International Journal of Control and Automation, 13 (4), 1088-1099.

[6] Nagpal, S.W. (2020). Pandemic Year:Evolution of e-Learning. Journal of Educational \& Psychological Research, $10(1$ \& 2), 87-88.

[7] Singh, B. (2017). Digital Initiatives for Indian Higher Education. International Journal of Advanced Research in Computer Science, 8(7), 1042-1044.

[8] MHRD. (2020). Digital Initiatives in Higher Education. Retrieved December 15, 2020 from https://gndec.ac.in/sites/default/files/Digital\%20IC T\%20Initiatives_MHRD.pdf

(9]) MHRD. (2020). India Report Digital Education.Retrieved December 25, 2020 from https://www.education.gov.in/sites/upload_files/m hrd/files/India_Report_Digital_Education_0.pdf

[10] Mc Carthy, N. (2020, March 24). UNESCO: COVID-19 School Closures Have Impacted Nearly 1.4 Billion Students [Infographic]. Forbes.Retrieved February 15, 2021 from https://www.forbes.com/sites/niallmccarthy/2020/ 03/24/unesco-covid-19-school-closures-haveimpacted-nearly-14-billion-studentsinfographic/?sh=797f987d3dd5

[11] Fernandes, A. J. (2020). Impact of Covid19:University Students' Perspective. International Journal of Nutrition, Pharmacology, Neurological Diseases, 10 (3), 168-169.

[12] UNESCO. (2020).UNESCO'S support: Educational response to COVID-19. Retrieved December 24, 2020, from WWW.UNESCO.ORG: https://en.unesco.org/covid19/educationresponse 
[13] Mustafa, N. (2020). Impact of the 2019-20

Corona Virus Pandemic on Education.

International Journal of Health Preferences

Research, 5 (20).Retrieved January 10, 2021 from

https://www.researchgate.net/publication/3408499

56_Impact_of_the_2019-

20_coronavirus_pandemic_on_education

[14] Gulati, K. (2020). Impact of Covid 10

Pandemic on Education System in india and world

wide. Retrieved from

https://www.longdom.org/abstract/impact-of-

covid-10-pandemic-on-education-system-in-indiaand-world-wide-57328.html

[15] Nambiar, D. (2020). The impact of offline learning during COVID 19: Students' and teachers' perspective. The International Journal of Indian Psychology, 8 (2). 